\title{
Biocatalyst: Phytase Production in Solid State Fermentation by OVAT Strategy
}

\author{
Somy Soman 1(D), Suresh Kumarasamy 1,*(D), Mathiyazhagan Narayanan ${ }^{1}$ (D), \\ Muthusamy Ranganathan 1 (D) \\ 1 PG and Research centre in Biotechnology, MGR College, Hosur, Tamilnadu, 635130, India \\ * Correspondence: sureshbioteck@yahoo.com;
}

Scopus Author ID 57195420982

Received: 11.04.2020; Revised: 30.04.2020; Accepted: 1.05.2020; Published: 3.05.2020

\begin{abstract}
The phytase-producing Pichia membranifaciens S3 (MG663581) was isolated from sugarcane juice using phytase screening medium. The predicted and experimental model showed maximum phytase production of $364 \mathrm{U} / \mathrm{ml}$ appearing $\mathrm{g} / 100 \mathrm{ml}$ : Jack fruit seed (1.5), peptone (0.15), dextrose $(0.50)$, yeast extract $(0.05)$, malt extract $(0.05) \mathrm{pH} 5.5$ and $\left.28^{\circ} \mathrm{C}\right)$ used OVAT strategy by Solid state fermentation through shake flask methodology. The modelling, 3D structure of Phy S3 amino acid sequences was modelled (PhyS3.B99990003) by using Modeler 9.23 and validated results showed that $86.4 \%$ in the favoured region by Ramachandran plot.
\end{abstract}

Keywords: Yeast; jack fruit seed powder; PSM medium; Ramachandran plot; Pichia membranifaciens; one source variable at a time.

(C) 2020 by the authors. This article is an open access article distributed under the terms and conditions of the Creative Commons Attribution (CC BY) license (https://creativecommons.org/licenses/by/4.0/).

\section{Introduction}

Enzymes are biocatalysts and large macromolecules integrated of polymers of essential or non-essential amino acids connected by amide bonds [1]. Microorganisms are the favoured sources of enzymes, because they are fast growth in large quantities in minimum period and easy availability. In addition, they play an economical role in metabolic and biochemical reactions in the enzyme production [2].Phytase is universally availed in nature like in different microorganisms, in which interest has increased remarkably in the past decades[3].

Phytases (EC 3.1.3.8 ;phosphomonoesterases) primary enzymes having catalyse the hydrolysis of phytate into lower forms of myo-inositol 1,2,3,4,5,6-hexakis dihydrogen phosphate, in rarely free myo inositol phosphates and inorganic phosphate (Ins P5 to P1) [4]. However, phytases are liberated of $\mathrm{P}$ moiety from phytic acid at the position phytases, three types namely (C3) 3-phytase (EC 3.1.3.8), (C5) 5-phytase (EC 3.1.3.72) and (C4) 4-phytase (EC 3.1.3.26) respectively. Hence, phytases are considered to be a noteworthy candidate for use as an enzyme that has great value in enhancing nutrient factors from soil, therefore, phytase enzyme would be an eco-friendly product [4].

Yeasts are known as a potential for producing economical industrial important enzymes, Therefore, Pichia sp generally regarded as safe (GRAS) strains are involved in production of extracellular and cell bound phytases and to develop large scale industrial production in economical mode. Yeast like Zygosaccharomyces priorionus NCIM 3299 Zygosaccharomyces bisporus NCIM 3265 Schizosaccharomyces octosporus NCIM 3297 3296, and Williopsis saturnus NCIM 3298 ) has been successfully bring about using 
cultivation process of solid state fermentation [5]. Hence, in the past 20 years, several investigators have optimized the nutritional and physical parameters for maximizing the production of yeast phytases [6-9].

In the present investigation,we isolated, identified Pichia $s p$ and screened to be a potent phytase producer. Optimal culture conditions and fermentation parameters were assessed for most effective nutrients to enhance phytase production by Solid state fermentation Furthermore, have been identified and purified to near-homogeneity by protein sequence homology, the 3D structure of the protein.

\section{Materials and Methods}

\subsection{Sample collection site description.}

Wild yeast strains were isolated from sugarcane juice collected from Dharmapuri Cooperative Sugar Mills, Pallacode, Dharmapuri in a sterile container. The collected juice sample was serially diluted $10^{-5}$ to $10^{-9}$ and plated on dextrose $(2 \mathrm{~g})$, yeast extract $(1 \mathrm{~g})$, malt extract, peptone $(1 \mathrm{~g})$, agar $(1.7 \mathrm{~g})$ in $100 \mathrm{ml}$ of sterile distilled water and incubated at $30^{\circ} \mathrm{C}$ for $48-72 \mathrm{~h}$ respectively. After the incubation period of $48 \mathrm{~h}$, dominative colonies were selected based on shape, color, margin, elevation. Pure culture was prepared by streak plate method. Yeast cultures were maintained on $2 \%$ YPMD slants at $4^{\circ} \mathrm{C}$ for short period storage [10].

\subsection{Primary screening of phytase producing isolate.}

One loop full of dominative isolate was plated onto phytase screening media (PSM) plates containing (g/100ml):1.5 Dextrose, 0.5 phytic acid, $1 \mathrm{NaNO}_{3}, 0.5 \mathrm{MgSO} 4.7 \mathrm{H}_{2} \mathrm{O}, 0.5$ $\mathrm{KCl}, 0.01 \mathrm{FeSO}_{4} .7 \mathrm{H}_{2} \mathrm{O}, 0.01 \mathrm{MnSO} 4.6 \mathrm{H}_{2} \mathrm{O}, 1.5$ agar, $\mathrm{pH}$ 5.5.Plates were incubated at $30^{\circ} \mathrm{C}$ and checked for phytase production on the basis of the halo zone of hydrolysis around the colony (Kłosowski et al. 2018). The halo zoned isolate was carried for further work.

\subsection{Sequence and deposit.}

In genotypic characterization, extract genomic DNA from yeast cells, quantitate the genomic DNA and polymerase chain reaction (PCR) was carried out using the applied biosystem research thermal cycler. After amplification purify the amplified product using a PCR purification kit (orange). The sample was loaded on the machine and the data in form A, $\mathrm{C}$, $\mathrm{T}$, and $\mathrm{G}$ were released. The $16 \mathrm{~S}$ rRNA sequencing was carried out using the applied biosystem. The isolates' genes were sequenced using primer (5'-3') FP GCCTGTCTCAAAGATTAAGCC, RP- CACCTACGGAGACTTTGTTAC. The sequence result was identified based on the percentage (\%) similarity obtained from above was compared with known sequences in the Genbank using the Basic Local Alignment Search Tool (BLAST) of the National Centre for Biotechnology Information (NCBI). The identified sequence was submitted to blanket-NCBI (https://www.ncbi.nlm.nih.gov/BankIt) submission tool and also sequence has been deposited in the GenBank nucleotide sequence databases under Accession No. A phylogenetic tree was made in robust tree software using the Neighbor-joining method with Bootstrap analysis to obtain evolutionary relationships of taxa [11]. 


\subsection{Phytase production on Shake flask conditions.}

The initial optimization step was carried out (OVAT) shake flask conditions with different sources including peptone and dextrose were used as a carbon source in different concentrations of $(\mathrm{g} / 100 \mathrm{ml})(0.15-0.55),(0.25-1.25)$. Yeast extract and malt extract were used as nitrogen source in different concentration of (0.05- 0.25), (0.05-0.25) with the Jackfruit seed powder concentration $(0.5-2.5) \mathrm{pH}$ to $(5.5-9.5)$, temperature at $28,30,32,37$ and $40^{\circ} \mathrm{C}$.

\subsection{Phytase production and assay.}

Solid-state fermentation was carried out optimized sources of peptone 0.15 , dextrose 0.5 , yeast extract 0.05 , malt extract 0.05 , substrate with jackfruit seed powder $(1.5 \mathrm{~g} / 100 \mathrm{ml})$ and add $1 \mathrm{ml}$ Pichia sp S3 $\left(10^{8}\right.$ cells $\left.\mathrm{mL}-1\right)$ of culture, condition was maintained at $\mathrm{pH} 5.5$ and temperature $28^{\circ} \mathrm{C}$ [12]. The shaker was run with agitation $150 \mathrm{rpm}$ for $72 \mathrm{~h} .20 \mathrm{ml}$ of sample was withdrawn at $72 \mathrm{~h}$ and analyzed for phytase activity assay using (trichloroacetic acid, Taussky shorr color reagent) [13] and protein estimation using folin ciocalteu reagent [14].The activity of the enzyme was expressed as units per $\mathrm{ml}$ for the reaction.

\subsection{Partial Purification of Phytase by APS, Dialysis, DEAE-Column chromatography.}

All three purification processes were carried out at $4^{0} \mathrm{C}$ in laboratory. The collected crude extract of Proteins was precipitated using ammonium sulphate [15]. They were fractioned $20 \mathrm{ml}$ crude extract with the addition of ammonium sulphate until different saturation levels were reached $(20-80 \%)$ under magnetic stirrer. The collected precipitate was transfer to centrifuge tube and pelleted by centrifugation at $15,000 \mathrm{rpm}$ for $20 \mathrm{~min}$ at $4^{\circ} \mathrm{C}$ and pellets resuspended in a $20 \mathrm{mM}$ and $\mathrm{pH} 7.5$ Tris- $\mathrm{HCl}$ buffer. and assayed activity of phytase.

The highest phytase activity suspension was desalted in a $12 \mathrm{~cm}$ dialysis bag against the Tris- $\mathrm{HCl}$ buffer overnight under magnetic stirring with a frequent change to remove the residual $\left(\mathrm{NH}_{4}\right)_{2} \mathrm{SO}_{4}$. The dialyzed protein was again centrifuged $10000 \mathrm{rpm}$ for $5 \mathrm{~min}$ to remove any insoluble particulate matter [16].The dialyzed solution was then poured to DEAECellulose anion exchange column $(2 \mathrm{~cm} 10 \mathrm{~cm})$, equilibrated with $20 \mathrm{mM}$ Tris- $\mathrm{HCl}$ buffer and eluted with a $(0.5$ and $1.0 \mathrm{M}) \mathrm{NaCl}$. The fractions were pooled, concentrated [17]. At three stage of purification process, total protein content of the fractions by Lowry's method with BSA was used as the standard curve at $595 \mathrm{~nm}$ and phytase activity were analysed.

\subsection{Homology modelling Phy S3 protein.}

Homology 3D protein modeling of selected Phy S3 protein Pichia membranifaciens (MG663581)sequence was performed, using its suitable best-matched homologous sequences for building the 3D structure was searched against PDB using BLAST-RCSB and alignment file was used to build the model using the automated homology modeling tool MODELER 9.23.Evaluation of the predicted protein model was done by SAVES server (http://servi ces.mbi.ucla.edu/SAVES/). Based on the generated result, the best built model was finally submitted to Protein Model Database (PMDB) and the PMDB ID was acquired [18]. 


\section{Results and Discussion}

\subsection{Isolation and screening of phytase producer.}

A total of ten yeast strains were isolated in YPMD medium from the sugarcane juice samples collected at Dharmapuri Co-operative Sugar Mills. All the isolates were screened on phytase producing medium containing $0.5 \%$ phytic acid as the substrate. Among the ten yeast isolates, one isolate $\mathrm{S} 3$ was picked on the basis of the clearing zones around the colonies in PSM medium (Figure 1a). Accordingly, this isolate was chosen for further investigations.

\subsection{Phenotypic characterization.}

Strain S3 (Figure 1b) showed that the arrangement of few buds but many prominent bud scars on individual cells rounded or slightly elongated had a smooth surface and interconnecting processes. It depicted bipolar young budding yeast cells under 3000x magnification.

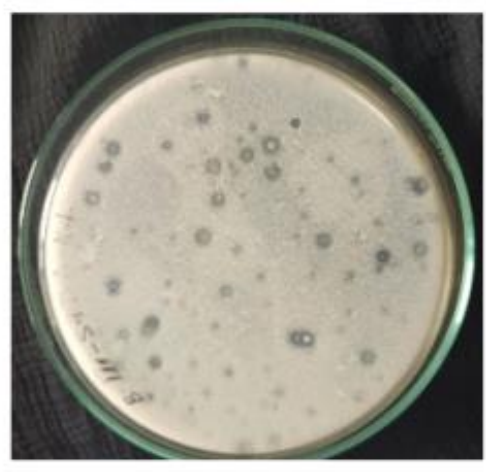

a

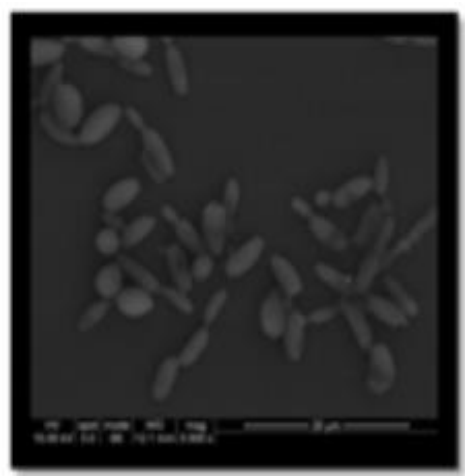

b

Figure 1. Pichia membranifaciens S3 a) Clear zone around S3, b) SEM image: intact colonies.

\subsection{Genotypic characterization.}

Yeast isolate S3 was subjected to molecular identification using 16S rRNA. The 16S rRNA gene was amplified by PCR. The amplified product, with reference to the marker used, was estimated to be amplicon approximately $290 \mathrm{bp}$. The 16S rRNA sequence of the S3 shows the phylogenetic relationship and closest similarity $\{100 \%\}$ with Pichia membranifaciens available in NCBI-BLAST database, the optimal tree with the sum of branch length $=0.1501$ (Figure 2). The partial sequence of 16S rRNA gene was submitted in Blankit tool and accessed the GenBank accession number MG663581. Several authors reported the production of phytase using variety of yeast [19]. However, few studies made an attempt for the Pichia sp used for phytase production by Pichia membranifaciens, Pichia membranifaciens [20]. However, there is no report on potential phytase producing Pichia membranifaciens S3 isolated from sugarcane juice streams utilizing jackfruit powder as potential substrates.

\subsection{Phytase production optimization by SSF.}

During ssf, all the nutrient sources were supplied for the microbial growth and phytase production. Thus, different five concentrations of two carbon sources and two nitrogen sources were investigated for their efficacy on phytase production. Among different concentrations of peptone sources, $0.15 \mathrm{~g} / 100 \mathrm{ml}$ produced a highest phytase activity and biomass $\{364 \pm 0.71$ 
$\mathrm{U} / \mathrm{ml}\}\{1.76 \pm 0.32\}$ than other concentrations similarly, dextrose in $\{364 \pm 0.24 \mathrm{U} / \mathrm{ml}\}\{1.31$ \pm 0.18 \} activity in $0.15 \mathrm{~g} / 100 \mathrm{ml}$ (Figure 3 ). Similarly reported that supplementation of carbon sources increased significant phytase production [21].

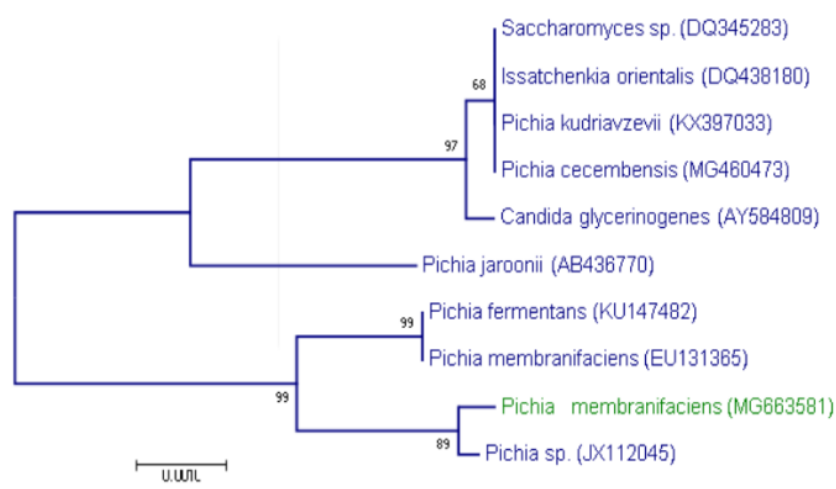

Figure 2. Phylogenetic and evolutionary relationships taxa of Pichia membranifaciens S3 (MG663581).

The medium supplemented with yeast extract and malt extract respectively, $0.05 \mathrm{~g} / 100 \mathrm{ml}$ produced a highest phytase activity and biomass $\{364 \pm 0.57 \mathrm{U} / \mathrm{ml}\}$ $\{1.56 \pm 0.32\},\{364 \pm 0.27 \mathrm{U} / \mathrm{ml}\}\{1.82 \pm 0.51\}$ than the other concentrations. Many authors reported that the same concentration which produces highest phytase activity [22]. The inoculated flasks were kept for incubation at five different temperatures discrete from $\{28$ $\left.40^{\circ} \mathrm{C}\right\}$. The results showed that the highest activity of phytase $\{364 \pm 0.34 \mathrm{U} / \mathrm{ml}\}$ was obtained at $28^{\circ} \mathrm{C}$. After that, the phytase activity decreased gradually with the increase in incubation temperatures. A similar result was reported by author [22]. Results showed that the shift of $\mathrm{pH}$ backward the acidic side resulted in a highest phytase productivity.
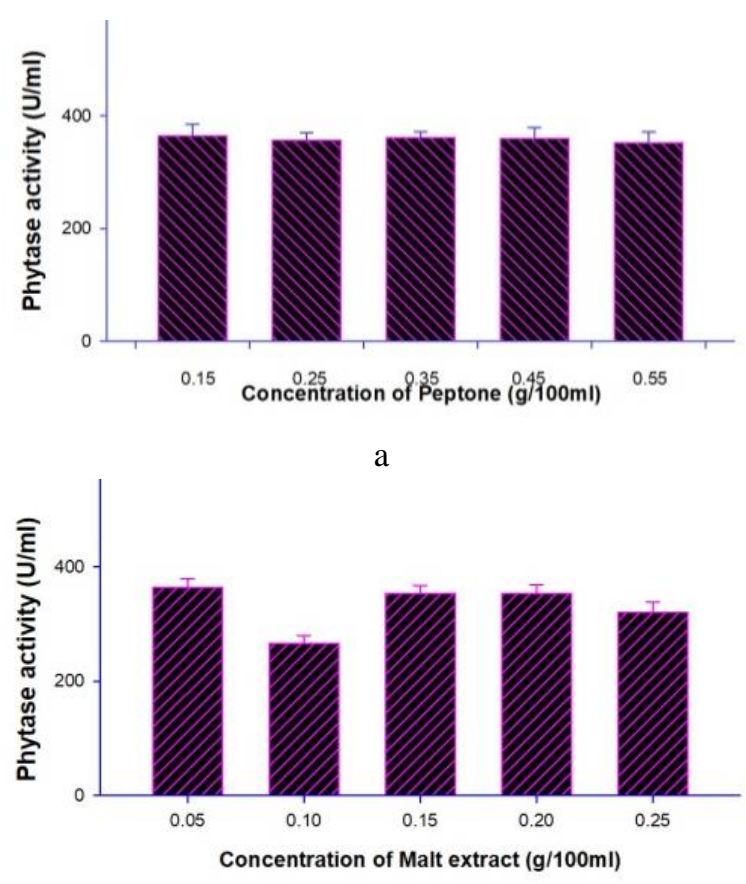

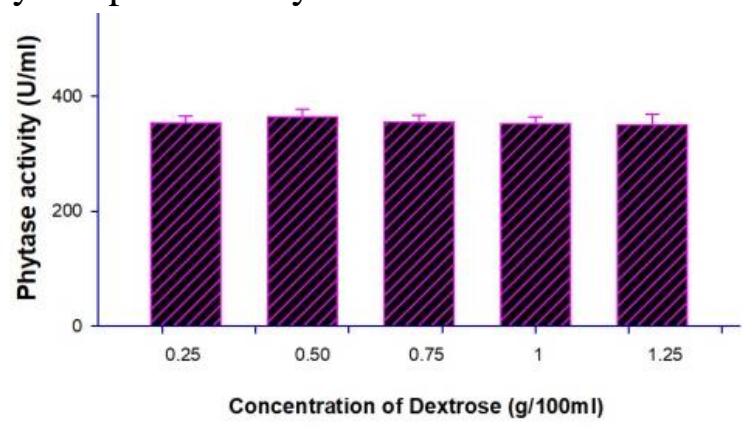

$\mathrm{b}$

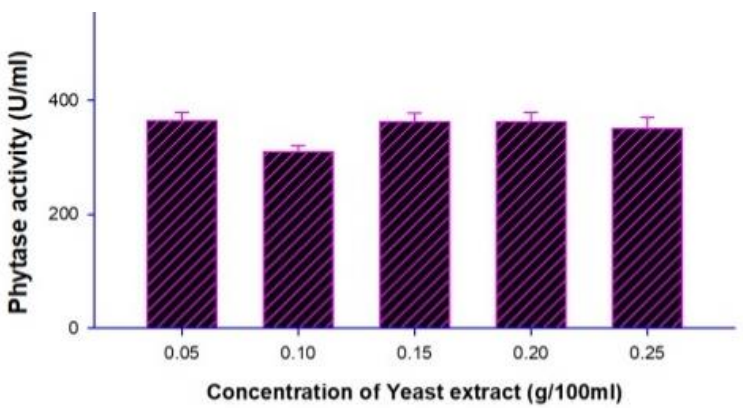

d

Figure 3. Effect of different concentration of sources for production of Phytase a) Peptone b) Dextrose c) Yeast extract d) Malt extract

The maximum phytase activity of $364 \pm 0.32$ was obtained at $\mathrm{pH} 5.5$, after that there was a gradual decrease in phytase production. The results in the present study indicated that maximum phytase activity of $364 \pm 0.16$ was obtained phytic acid concentration of $0.15 \mathrm{~g} / \mathrm{ml}$. 
In earlier studies reported that similar results by Hussin et al.2010.The present work was started by the effect of production phytase by using 5 concentrations of agro industrial residues. The results in Figure 4 showed that Maximum phytase productivity $\{394 \pm 0.17 \mathrm{U} / \mathrm{ml}\}$ was achieved with $0.20 \mathrm{~g} / \mathrm{ml}$.

\subsection{Partial Purification.}

The phytase activity of the crude culture supernatant was highest when medium obtained after optimization of nutritional parameters \{peptone,dextrose ,yeast extract,malt extract $\}$ and culture conditions $\left\{\mathrm{pH}-5.5\right.$,Temperature $\left.28^{\circ} \mathrm{C}\right\}$ incubated for $72 \mathrm{~h}$. Thus, enzyme was first concentrated by ammonium sulphate fractionation and the aimed protein was detected in the precipitate saturation after $30 \%$ salt cut process. After removal of ammonium sulphate by dialysis membrane for overnight with stirrer, followed by protein was purified by DEAE anion exchanger with elution buffer. Table 1 showed that phytase activity and protein fold. At the end of the purification process, the phytate was purified 3.67 fold with a recovery of 43.6 $\%$. The specific activity was increased up to $41.8 \mathrm{U} \mathrm{mg}-1$ of total protein, in reported similar results [23].

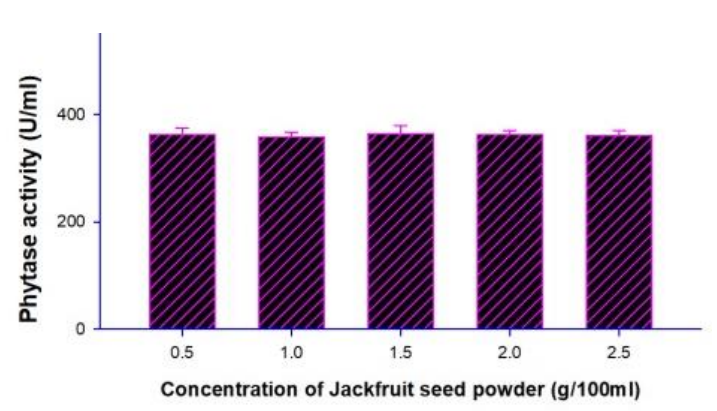

a

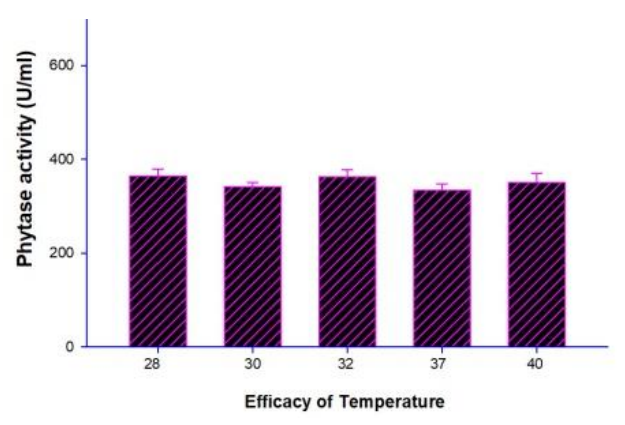

b

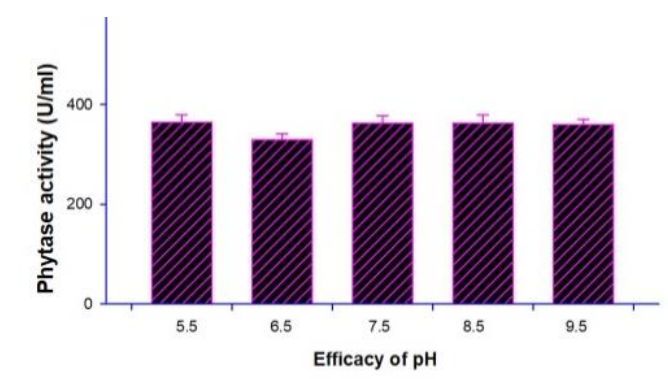

c

Figure 4. Effect of different concentration and conditions for production of Phytase a) Jack fruit seed powder $\mathbf{b}$ ) Temperature c) $\mathrm{pH}$.

\subsection{In silico method for prediction of secondary structure.}

The predicted secondary arrangements of alpha-helix $\{\mathrm{Hh}-40.63 \%\}$, random coils $\{\mathrm{Cc}-$ $45.24 \%\}$, extended strands $\{$ Ee-8.65\% $\}$ and beta turns $\{\mathrm{Tt}-5.48 \%\}$ were found in Pichia membranifaciens S3 results by NPS@ SOPMA secondary structure prediction. Previously also reported that alpha-helical content $\{42.76 \%\}$ was found 3-phytase B, respectively [24]. 
Table 1. Partial purified Phytase and protein concentration.

\begin{tabular}{l|c|c|c|c|c}
\hline \multicolumn{1}{c|}{$\begin{array}{c}\text { Purification } \\
\text { conditions }\end{array}$} & $\begin{array}{c}\text { Total } \\
\text { Protein } \\
\mathbf{m g / m l}\end{array}$ & $\begin{array}{c}\text { Total } \\
\text { phytase } \\
\text { activity } \\
\text { U/ml }\end{array}$ & $\begin{array}{c}\text { Specific } \\
\text { activity } \\
\text { U/mg } \\
\text { Protein }\end{array}$ & $\begin{array}{c}\text { Purification } \\
\text { (fold) }\end{array}$ & $\begin{array}{c}\text { Yield } \\
(\%)\end{array}$ \\
\hline Crude supernatant & 32 & 364 & 11.37 & 1 & 100 \\
\hline $\begin{array}{l}\text { Ammonium } \\
\text { sulphate } \\
\text { precipitation }\end{array}$ & 8 & 318 & 39.75 & 3.5 & 87.3 \\
\hline Dialysis & 7.2 & 298 & 41.3 & 3.63 & 81.8 \\
\hline $\begin{array}{l}\text { DEAE celloulose } \\
\text { ion exchange } \\
\text { chromatography }\end{array}$ & 3.8 & 159 & $\mathbf{4 1 . 8}$ & $\mathbf{3 . 6 7}$ & $\mathbf{4 3 . 6}$ \\
\hline
\end{tabular}

\subsection{Homology modelling.}

Modeller 9.23 was used to develop the 3D structure by providing the sequence alignment file $\{$ PhyS3-Pichia membranifaciens S3\}, template file $\{$ pdb_95\}, and target file \{1qwo, 1qfx, 2gfi, 1sk8, 3k4p\} (Figure 5). A similar type of homology model validation was also studied previously [25] while working with Aspergillus phytases. After the construction of $3 \mathrm{D}\{. \mathrm{pdb}\}$ model, the evaluation and quality estimation of the model were performed. The satisfactory of the generated model \{PhyS3.B99990003\} was assessed by using the general stereo chemical parameters by SAVES server.
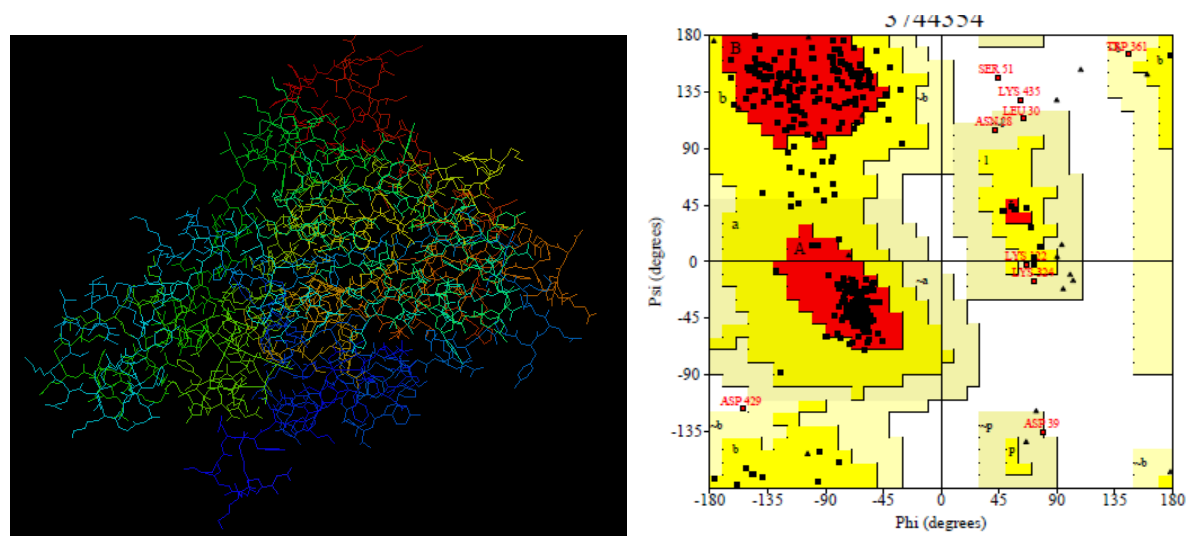

Figure 5. Wireframe diagrams of the modelled Phytase (ID: PM0083054) and Ramachandran plot.

Ramachandran 448 plot of energy minimized model of phytase structures had been generated. The result showed $86.4 \%$ of the residues within the most 344 favorable region, $11.3 \%$ within the moreover allowed region (Figure 5). After that, the model $\{$ in .pdb format $\}$ was deposited in PMDB database and received accession number ID: PM0083054.This structural finding was also studied some earlier reports. The presence of more than $97 \%$ residues in the most favoured region of Ramachandran plot was the characteristics of the good quality model [26].

\section{Conclusions}

In this study, we have concluded that Pichia membranifaciens S3 (MG663581) produces a uniquely stable phytase using substrate Jack friut seed powder under SSF with optimized design of shake flask. It has been suggested that our research introduced a low cost medium and very simple technique. In silico and homology model of this study states that 3D structure of protein model designs. Our work will have concluded that high benefits and suitable for large scale production. 


\section{Funding}

This research received no external funding.

\section{Acknowledgments}

\section{The authors would like to thank, PG and Research Centre in Biotechnology, MGR College, Hosur, Tamilnadu for their technical support.}

\section{Conflicts of Interest}

The authors declare no conflict of interest.

\section{References}

1. Singh, R.; Kumar M.; Mittal, A.; Mehta, P.K. Microbial enzymes: industrial progress in 21st century. 3 Biotech 2016, 6, http://doi.org/10.1007/s13205-016-0485-8.

2. Thapa, S.; Li, H.; OHair, J. Biochemical characteristics of microbial enzymes and their significance from industrial perspectives. Mol Biotechnol 2019, 61, 579-601, https://doi.org/10.1007/s12033-019-00187-1.

3. Jatuwong, K.; Suwannarach, N.; Kumla, J.; Penkhrue, W.; Kakumyan, P.; Lumyong, S. Bioprocess for production, characteristics, and biotechnological applications of fungal phytases. Front Microbiol 2020, 11, https://doi.org/10.3389/fmicb.2020.00188.

4. Castillo Villamizar, G.; Nacke, A.; Griese, H.; Tabernero, L.; Funkner, L.K.; Daniel, R. Characteristics of the first protein tyrosine phosphatase with phytase activity from a soil metagenome. Genes 2019, 10, https://doi.org/10.3390/genes10020101.

5. $\quad$ Pires, E.B.E .; de Freitas, A.J.; Souza, F.F. Production of Fungal Phytases from Agroindustrial Byproducts for Pig Diets. Sci Rep 2019, https://doi.org/10.1038/s41598-019-45720-z.

6. Klosowski, G.; Mikulski, D.; Jankowiak, O. Extracellular phytase production by the wine yeast S. cerevisiae (Finarome Strain) during submerged fermentation. Molecules 2018, 23, 848, https://doi.org/10.3390/molecules23040848.

7. Muslim, S.N.; Mohammed Ali, A.N.; AL-Kadmy, I.M.; Khazaal, S.S.; Ibrahim, S.A.; Al-Saryi, N.A.; AlSaadi, L.G.; Muslim, S.N.; Salman, B.K.; Aziz, S.N. Screening, nutritional optimization and purification for phytase produced by Enterobacter aerogenes and its role in enhancement of hydrocarbons degradation and biofilm inhibition. Microb Pathog 2018, 115, 159-167, https://doi.org/10.1016/j.micpath.2017.12.047.

8. Shahryari, Z.; Fazaelipoor, M.H.; Setoodeh, P. Utilization of wheat straw for fungal phytase production. Int J Recycl Org Waste Agricult, 2018,7, 345-355, https://doi.org/10.1007/s40093-018-0220-z.

9. Ajith, S.; Shet, D.; Ghosh, J.; Elangovan, A.V. Immobilised phytase production from Aspergillus foetidus MTCC 11682 using an optimized media. Biotechnol J Int 2018, 21, 1-13, https://doi.org/10.9734/BJI/2018/43071.

10. Vasuki, S.; Suresh, K. Phenotypic, genotypic characterization and racemic monochlorohydrin assimilating yeast from sugar cane juice. Research Journal of Chemistry and Environment 2017, 21, 1-6.

11. Vasuki, S.; Suresh, K. Bio mat formation and in vitro growth of Candida species isolated from sugarcane juice. Research Journal of Biotechnology 2017, 12, 8-14.

12. Ajith, S.; Ghosh, J.; Shet, D.; Vidhya, S.; Punith, B.D.; Elangovan, A.V. Partial purification and characterization of phytase from Aspergillus foetidus MTCC 11682. AMB Expr 2019, 9, https://doi.org/10.1186/s13568-018-0725-X.

13. Madsen, C.K.; Brearley, C.A.; Brinch-Pedersen, H. Lab-scale preparation and QC of phytase assay substrate from rice bran. Anal Biochem 2019, 578, 7-12, http://doi.org/10.1016/j.ab.2019.04.021.

14. Maehre, H.K.; Dalheim, L.; Guro, K.; Edvinsen, E.O.; Elvevoll.; Jensen, I.J. Protein determination-method matters. Foods 2018, 7, http://doi.org/10.3390/foods7010005.

15. Sanni, D.M.; Lawal, O.S.; Enujiugha, V.N. Purification and Characterization of Phytase from Aspergillus fumigatus Isolated from African Giant Snail (Achatina fulica). Biocatalysis and Agricultural Biotechnology 2019, 17, 232-245, https://doi.org/10.1016/j.bcab.2018.11.017.

16. Puppala, K.R.; Naik, T.; Shaik, A.; Dastager, S.; Ravi Kumar, V.; Khire, J.; Dharne, M. Evaluation of Candida tropicalis (NCIM 3321) extracellular phytase having plant growth promoting potential and process development, Biocatalysis and Agricultural Biotechnology 2018, 13, 225-235, https://doi.org/10.1016/j.bcab.2017.12.013.

17. Sharma, B.; Shukla, G. Optimisation, Purification and Characterisation of Phytase from Isolated Probiotic Pediococcus acidilactici BNS5B. Int. J. Curr. Microbiol. Appl. Sci. 2019, 8, 2060-2081, https://doi.org/10.20546/ijcmas.2019.809.238. 
18. Pramanik, K.; Kundu, S.; Banerjee, S.; Ghosh, P.K.; Maiti, T.K. Computational-based structural, functional and phylogenetic analysis of Enterobacter phytases. 3 Biotech 2018, 8, https://doi.org/10.1007/s13205-0181287-y.

19. Wang, Y.; Zhao, Y.C.; An, L.L.; Xia, X.D.; Huili, Y.; Zhou, J.Z. Identification and characterization of Pichia membranifaciens Hmp-1 isolated from spoilage blackberry wine. Journal of Integrative Agriculture 2019, 17, 2126-2136, https://doi.org/10.1016/S2095-3119(18)62027-1.

20. Johansen, P.G.; Owusu-Kwarteng, J.; Parkouda, C.; Padonou, SW.; Jespersen, L. Occurrence and importance of Yeasts in indigenous fermented food and beverages produced in sub-saharan Africa. Front. Microbiol 2019, 10, https://doi.org/10.3389/fmicb.2019.01789.

21. Ornela, P.H.; Guimaraes, LHS. Purification and characterization of an alkalistable phytase produced by Rhizopus microsporus var. microsporus in submerged fermentation. Process Biochem 2019, 81, 7076, https://doi.org/10.1016/j.procbio.2019.03.015.

22. Ke, Y.; Wei, M.Y.; Fu, Y.T.; Zhu, Y.M.; Zhan, X.L. Study on cloning, expression and hydrolysis characteristics of Aspergillus niger protease (pepD) gene. Protein Expression and Purification 2019, 162, 67-71.

23. Sanni, D.M.; Lawal, O.T.; Enujiugha, V.N. Purification and characterization of phytase from Aspergillus fumigatus isolated from African Giant Snail (Achatina fulica). Biocatal. Agric. Biotechnol 2019, 17, 225232, https://doi.org/10.1016/j.bcab.2018.11.017.

24. Suresh, S.; Radha, K.V. Statistical optimization and mutagenesis for high level of phytase production by Rhizopus oligosporus MTCC 556 under solid state fermentation. J Environ Biol 2016, 37, 253.

25. Tian, M.; Yuan, Q. Optimization of phytase production from potato waste using Aspergillus ficuum. 3 Biotech 2016, 6, https://doi.org/10.1007/s13205-016-0573-9.

26. Trivedi, S.; Sharma, A.; Jain, P. Enhancement of Phytase Production from a New Probiotic Strain Bacillus subtilis P6. Int. J. Curr. Microbiol. App. Sci. 2017, 6, 2744-2759, https://doi.org/10.20546/ijcmas.2017.606.328. 